\title{
Rosta Miklós
}

\section{Állampolgári Érdek Mutató}

\author{
Javaslat az új közszolgálati menedzsment \\ eredményességének mérésére
}

\begin{abstract}
A jelen tanulmány egy olyan mutatót kiván bevezetni, amellyel lehetővé válik az új közszolgálati menedzsment átfogó, makroszintü eredményességének értékelése. A szerző amutató megalkotása során a közösségi döntések elméletéből indul ki, mivel az új közszolgálati menedzsment politikaelméleti és közgazdaság-tudományi alapjai szorosan köthetöek ezen elmélethez. A megalkotott kompozit indexet nem csak elméletben mutatja be, hanem tartalmilag és módszertanilag is ismerteti. ${ }^{1}$
\end{abstract}

Journal of Economic Literature (JEL) kód: H83, D70, D23

Kulcsszavak: Új Közszolgálati Menedzsment, intézményi közgazdaságtan, közösségi döntések elmélete, Állampolgári Érdek Mutató

A jelen tanulmányban az új közszolgálati menedzsment (New Public Management NPM) irányzat közgazdaságtudományi gyökereiből kiindulva javaslatot teszünk egy olyan mutatóra, amelynek használatával képesek lehetünk az irányzat eredményességét makroszinten értékelni. ${ }^{2}$ Célunk a mutató elméleti bevezetésére korlátozódik, annak empirikus tesztelésére a jelen tanulmány keretei között nem vállalkozunk. ${ }^{3}$ Az NPM irányzateredményességét mérő mutató megalkotásának kérdése akkor is releváns, ha az irányzatot már hosszú ideje temeti a tudományos közélet, míg a gyakorlati alkalmazását a jelenleg is tartó gazdasági válság szorította háttérbe. ${ }^{4}$ Megkérdőjelezhetetlen, hogy az elmúlt pár évben az irányzathoz leginkább közel álló országokban, azaz az Egyesült Királyságban és Uj-Zélandon is az irányzat szemléletmódjával ellentétes kormányzati lépésekre került sor. A fejlett, nyugati világ számos országát felsorolhatnánk, ahol az állami szerepvállalás erősödése figyelhető meg. Nem kivétel e folyamatok alól Magyarország sem. A kormányok

Rosta Miklós a Budapesti Corvinus Egyetem Összehasonlitó Gazdaságtan Tanszékén egyetemi tanársegéd, a Nemzetközi Kapcsolatok Doktori Iskola doktorjelöltje. E-mail:miklos.rosta@uni-corvinus.hu.

1 A tanulmány a TÁMOP 4.2.1. B 09/1/KMR-2010.0005 számú támogatási szerződés keretében készült. A szerző köszöntet mond Prof. Dr. Hámori Balázsnak és Prof. Dr. Szabó Katalinnak, Dr. Tóth Lászlónak, Koltai Júliának és az anonim lektoroknak a tanulmány megírásához nyújtott segítségükért.

2 Az NPM fogalmát a következö fejezetben részletesen bemutatjuk. Most csak annyit jegyzünk meg, hogy az irányzat az 1980-as évek elején indult hódító útjára az angolszász országokban, és életciklusa elején alapvetően a piaci koordinációt és a profitorientált vállalkozásoknál használt menedzsmenteszközök alkalmazását támogatta. Később - elsősorban a skandináv és a kontinentális, nyugat-európai országok reformgyakorlata alapján - ez kiegészült az ügyfél-orientáció és a részvétel elvének támogatásával.

${ }^{3}$ A mutatót empirikusan a doktori disszertációnkban kivánjuk tesztelni.

4 Az NPM irányzat kritikai elemzésével kapcsolatban lásd: Denhardt - Denhardt (2000); Dunleavy et al 2005; Hughes (2008); Lapsley (2009). 
a piaccal szemben nagyobb szociális biztonságot kívánnak nyújtani az állampolgáraiknak, egyben nagyobb gazdasági mozgásteret saját maguknak. A jelenlegi tendencia alapján a kormányzatok válasza egyértelmű: erősebben támaszkodjunk a bürokratikus koordinációra és az állami tulajdonra, valamint szorítsuk vissza a magántulajdon és így a piaci koordináció hatalmát. A közgazdaságtannal és a piacokkal szembeni félelem és bizalmatlanság érezhetően fokozódott az állampolgárok körében, ezért a politikusok az állam gazdasági befolyásának növelésével kívánják javítani az állampolgárok biztonságérzetét és így saját szavazati arányukat.

A mostani válság és az NPM kapcsolatával nem kívánunk részletesen foglalkozni, de annak érdekében, hogy alátámasszuk tanulmányunk időszerüségét, világossá szeretnénk tenni az álláspontunkat ebben a kérdésben. Véleményünk szerint az NPM szemléletmódjának háttérbe szorulása átmeneti jelenség, mivel az állami beavatkozás - és így a bürokratikus koordináció-tranzakciósköltségei már rövid távon megfogjákhaladniaztaszintet, amelyetaz államok finanszírozni képesek. Az NPM irányzat számos, elsősorban az angolszász országok NPM-gyakorlatát meghatározó javaslata a válság után ismét középpontba fog kerülni a kapitalista gazdasági rendszerü demokratikus jogállamokban. Az NPM szemléletmódjából levezethetö menedzsmenteszközök, amennyiben a környezeti, intézményi és kulturális tényezőkhöz illeszkedve alkalmazzák azokat, képesek lesznek a bürokratikus koordináció felé túlzottan elmozduló ingát visszatéríteni a közgazdasági racionalitás és a piaci koordináció irányába. A bankok államosítása vagy forrásaik kormányzati intézkedésekkel történő elvonása, piaci vállalkozások felvásárlása, a pénzügyi források allokációjának centralizálása, bizonyos termékek árának állami meghatározása, állami vállalkozások költségvetési korlátjának puhítása az alapvető közgazdasági racionalitással megy szembe, amelynek költségeit minden esetben az állampolgárok fizetik meg. Ebből következően az állampolgárok saját érdekeik mentén fogják ismételten kikényszeríteni az állami szerepvállalás csökkentését és az állam hatékonyságának fokozását. Ennek eszköze az állam szerepének újraértékelése lesz, amely ismételten megnyitja majd az utat a liberális gazdaságpolitika előtt, amely szorosan köthető az NPM irányzathoz, és amely szemben áll a jelenleg folytatott totális állami gazdaságpolitikával. Csak reménykedni lehet, hogy az inga nem csap át a túloldalra, azaz a gazdasági szereplők tanulnak a múlt hibáiból: mind egy jól müködő, hatékony és a piaci kudarcokat hatékonyan kezelö államra, mind a magántulajdon szabadságra és a piaci koordináció egyedülálló hatékonyságára, innovativitására szükség van a fenntartható fejlődés érdekében.

Amennyiben a most felvázolt jövőkép helyes, úgy az NPM irányzatnak nemcsak a múltban, de a jövőben is hangsúlyos szerepe lesz a fejlett államok gazdaságpolitikájában. Így releváns kérdés annak vizsgálata, miként mérhető az irányzat eredményessége, illetve milyen feltételek esetén lehet eredményesen alkalmazni. ${ }^{5}$

5 2011-töl, az Európai Unió támogatásával, a 7. keretprogram keretein belül 10 ország 11 egyetemének közigazgatási szakértői keresik a jelen tanulmányban is felvetett kérdésekre a választ. A Coordination for Cohesion in the Public Sector of the Future nevet viselö kutatás az NPM értékelésére vállalkozik. Magyarországról a Budapesti Corvinus Egyetem Közgazdaságtudományi Karának Közszolgálati Tanszéke vesz részt a kutatásban, Dr. Hajnal György és Prof. Dr. Jenei György vezetésével. A kutatás eredményei a www.cocops.eu honlapon érhetőek el. 


\section{Az NPM fogalmának tisztázása és az elemzés elméleti kereteinek bemutatása}

Borins (2002) szerint az NPM egy új társadalmi szerződés, amelynek egyik oldalán az állampolgárok és a politikusok, míg a másik oldalon a bürokraták állnak. Ennek alapján az NPM irányzat úgy tekint a közpolitikai és közmenedzsment-folyamatokra, mint egy csereügyletre; a bürokraták jobb szolgáltatást nyújtanak, annak fejében, hogy nagyobb menedzseri szabadságot kaphassanak az erőforrásaik felett. A szerződés tartalmazza azon módszereket, amelyek segítségével a politikusok és az állampolgárok ellenőrizhetik és betartathatják a bürokraták vállalásait.

Christensen és Lægreid (2002) alapján az NPM-et leginkább az értékekben bekövetkezett változáson keresztül tudjuk megragadni. Véleményük szerint az irányzat erőteljes elmozdulást jelent a gazdasági racionalitás irányába, emberképe szorosan köthető a homo oeconomicus emberképéhez. ${ }^{6}$

Van de Walle és Hammerschmid (2011) a menedzseri innovációkat és a kormányzat szerepével kapcsolatos új gondolatokat emeli ki. Definíciójuk azért lényeges, mert rávilágít arra, hogy az NPM alapvetően a kormányzás szerepének, céljainak és értelmének újraértékelésére törekszik. Minden sikeres államigazgatási reform mögött erős és átlátható vízió húzódik meg, amely rögzíti, mi a célja az államnak, és milyen feladatokat kíván az államon keresztül megvalósítani. Az NPM irányzat hívei egyértelműen állást foglalnak ezekben a kérdésekben, még ha az általuk preferált ideális állapot most nem is túl populáris. E vízió alapján az NPM radikálisan hatékonyabb államot tart szükségesnek, amelyhez a piaci koordináció alkalmazását és a lakosság erőteljesebb bevonását javasolja.

Hood (1991:3) meghatározó művében az NPM négy „megatrendjét” azonosítja:

1. Az államigazgatás méretének csökkentése vagy legalább szinten tartása,

2. a központi állami vagyon privatizálása, vagy önkormányzatoknak való átadása,

3. a közszolgáltatások új szervezeti formáinak kialakítása,

4. az országspecifikus közigazgatási technikák helyett egy új, nemzetközi kooperációra és tudásmegosztásra épülö, a legjobb gyakorlatot felhasználó közigazgatási menedzsment kialakítása.

A fenti „megatrendekben” a célok és az eszközök keverednek, ami igen gyakori az NPMről szóló tanulmányokban. Ez az egyik oka annak, hogy sok gyakorlati szakember az eszköz bevezetésének megvalósításában látja az NPM-reformok sikerérét. Az adott menedzsmenteszköz alkalmazása önmagában válik céllá, annak hatásától függetlenül. E fogalmi keveredés jogos kritikát váltott ki az elméleti szakemberekből, és számos gyakorlati probléma forrásává vált. Annak érdekében, hogy ezt a hibát elkerüljük, érdemes definiálni, milyen valós célokat tüz zászlajára az NPM-mozgalom, s e célok megvalósítása érdekében milyen eszközrendszert javasol.

$\mathrm{Az}$ irányzat eredményességét holisztikusan és makroszinten vizsgáljuk. Ehhez szükségünk lesz valamilyen viszonyítási alapra, amelynek az alapján megítélhetjük, hogy az irányzat beváltotta-e a hozzá füzött reményeket ${ }^{7}$. Az NPM eredményeinek elemzése során Pollitt - Bouckaert 2004) négy szintet különböztet meg. Az első az operatív szint, amely

\footnotetext{
${ }^{6}$ A szerzők, akik az NPM irányzat legjelentősebb kritikusai közé tartoznak, az irányzat által elöidézett változásokat nem tartják üdvözítőnek.

7 Néhány fontosabb tanulmány, amely az NPM irányzat értékelésére vállalkozott: Hood 1995; Pollitt - Summa 1997; Barzelay 2001; Ferlie - Steane 2002; Wollmann 2003; Jones - Kettl 2003; Torres 2004; Gualmini 2008; Poór et al 2009; Van de Walle - Hammerschmid 2011.
} 
mérhető és jól definiálható. Erre példa, ha ugyanazon mennyiségü kiadás mellett növeljük egy adott szolgáltatás mennyiségét, akkor operatív szinten javul az eredményességünk. A második a folyamatok szintje, amely során a folyamatok átszervezésével javul a szervezet/ rendszer hatékonysága/eredményessége. A szerzők az egyablakos rendszer bevezetését hozzák fel példának, amelynél a folyamatok átszervezése révén növelhető az ügyfelek elégedettsége. Látható, hogy a folyamatok javítása operatív szinten is mérhető eredményt hoz: hatékonyabbá, eredményesebbé tehető egy adott szervezet, illetve azonos költséggel jobb színvonalú szolgáltatás nyújtható. A harmadik szint már absztraktabb: azállamigazgatás rendszerének mint egésznek a növekvő kapacitása. Az eredmények ezen szintjén alapvetően az intézményi változások sikere mérhető. Példa lehet, hogy az államigazgatásban az álláshelyek betöltése versenyeztetéssel zajlik, és a döntés eredménye a pályázó képességeitől függ, nem pedig a szervezeti hierarchiában éppen betöltött pozíciójától. Végezetül a reformok eredményessége úgy is megragadható, hogy a végrehajtott változások mennyiben közelítették az NPM által kijelölt ideális állapothoz az adott rendszert. Pollitt és Bouckaert szerint ez a szint ragadja meg leginkább a stratégiai eredményeket. Írásunkban Pollitt és Bouckaert (2004) negyedik, rendszerszintü, így leginkább holisztikus szemléletet tükröző eredményességi kategóriáját szeretnénk úgy konceptualizálni, hogy azt az NPM közösségi döntések elméletének gyökereiből vezetjük le.

Barzelay (2001) szerint az ideális állapot megragadásához egy megvalósult reformgyakorlatot érdemes kiválasztanunk. A London School of Economics professzora szerint esettanulmányok segítségével kiválasztható azon országok köre, amelyek gyakorlatához mérhetjük a többi országban megvalósuló reformokat. Barzelay (2001) könyvében ÚjZélandon, Ausztráliában és az Egyesült Királyságban megvalósult reformokat javasolja benchmarknak, megjegyezve, hogy azok egyaránt jó példái az NPM-reformoknak.

Schick (1998:124) nem ért egyet Barzelay fenti gondolatmenetével, mivel szerinte a külső környezeti tényezők minden ország esetében eltérnek, így az Új-Zélandon megvalósult reformgyakorlatot nem lehet feltétlenül követendö példaként javasolni. Schick arra is felhívja a figyelmet, hogy a fejlődő országokban a sikeres NPM reformoknak bizonyos előfeltételei nem állnak rendelkezésre, így számukra ezek a reformok kontraproduktívak lehetnek.

Ferlie és Steane (2002:1462) szintén rámutatnak az intézményi környezet fontosságára, de ők ezt kiegészítik a közigazgatási kultúra elemzésének szükségességével. Valóban, a kontinentális országok közigazgatási és jogi személete, joggyakorlata valamint közigazgatási kultúrája jelentősen eltér az angolszász országok gyakorlatától, és ez a különbség érdemben befolyásolhatja az adott ország közszektorában megvalósuló reformok szemléletét.

Egyetértünk Ferlie és Steane (2002:1461) gondolatával, hogy csak abban az esetben használhatjuk az angolszász országok példáját mintaként, és mérhetjük hozzájuk a többi ország NPM-gyakorlatát, ha elfogadjuk, hogy az NPM egy „anglo-amerikai termék”. Többen is - (Pollitt - Summa 1997), (Pollitt 2002), (Pollitt - van Thiel - Homburg 2007) elfogadták ezt a feltételezést. Hibázott-e Barzelay és a többi felsorolt szerző? Amennyiben az irányzat életciklusának korai szakaszára, azaz az 1980-as évekre és az 1990-es évek legelejére koncentráltak elemzésünkben, akkor nem hibáztak, mert az NPM-hez köthető szemléletmód és az abból levezethető menedzsmenttechnikák egyértelmüen az angolszász országokhoz kapcsolhatóak, és elsősorban azokban is terjedtek el. Az utóbbi évtizedekben azonban egyértelmủen módosult az irányzat fókusza, eszközrendszere bővült, s egyre sokszínübb lett. Az 1990-es évek közepétől a skandináv és a kontinentális országok NPM- 
gyakorlata is beépült az irányzatba, jelentősen módosítva annak egyfókuszú megközelítését. ${ }^{8}$ A nemzetközi szakirodalomban a reformgyakorlatát tekintve legtöbbet elemzett Új-Zéland példája pedig bizonyos szempontból kirívó eset, mivel a neoklasszikus és az új intézményi közgazdaságtani elvek olyan fokú elfogadására és használatára nem volt még precedens, mint ahogyan ezen elvek megjelentek a szigetországi reformokban. Erősen kérdéses, hogy egy extrém esetet szabad-e a többi ország számára követendő példaként felmutatni. (Ferlie - Steane 2002:1461)

\section{Az eredményesség mérésének elméleti kerete - A közösségi döntések elmélete}

$\mathrm{Az}$ előző fejezetben tisztáztuk az NPM fogalmát, megmutattuk, milyen szinten kívánjuk megragadni és mérni az irányzat eredményességét, illetve bemutattuk, hogy a szakirodalomban milyen lehetőségeket találtunk az eredményesség megragadására. Ezen javaslatokat nem tartjuk kielégítőnek és tudományosan védhetőnek, ezért a jelen fejezetben javaslatot teszünk az eredményesség mérésének módjára, s ehhez kapcsolódóan bemutatjuk, miként konceptualizáltuk az NPM eredményességének fogalmát. Ennek során a közösségi döntések elmélete, specifikusabban a gazdasági bürokráciaelmélet segítségével ragadjuk meg az NPM irányzat által kijelölt ideális állapotot. ${ }^{9}$ A közös fogalmi keret kialakítása érdekében röviden bemutatjuk a közösségi döntések elméletének szemléletmódját, illetve azon gondolatait, amelyek a jelen tanulmány témája szempontjából relevánsak.

A közösségi döntések elmélete a neoklasszikus közgazdaságtan axiómáira építve, annak emberképét elfogadva kíván magyarázatot adni a közösségi döntéshozatalban tapasztalható anomáliákra (Buchanan 1954; Buchanan 2003). Az elmélet hívei számára a politikus, a bürokrata, a választó, a lobbizó vállalkozó mind a saját önérdekét követö, racionális, preferenciákkal és korlátokkal rendelkező egyén, aki - aktívan vagy passzívan - saját céljaiért küzd a rendelkezésére álló eszközökkel. A közösségi döntések elmélete az egyéni érdekekből vezeti le a társadalmi folyamatokat, így olyan javaslatokat tesz, amelyek az egyéni viselkedés megváltoztatására irányulnak az intézményi környezet módosításával (Blankart - Koester 2006).

A Tullock - Buchanan ${ }^{10}$, Downsés ${ }^{11}$ Niskanen $^{12}$ nevével fémjelzett gazdasági bürokráciaelmélet a bürokratikus és a piaci szervezetek között tapasztalható hatékonyságbeli különbségeket az ott dolgozó aktorok egyénileg racionális viselkedéséből vezeti le (Eliassen Sitter 2008:95-99). A közösségi döntések elmélete szerint a bürokrácia által hozott döntések

\footnotetext{
${ }^{8}$ Az ezredforduló után számos közép- és kelet-európai ország, így Magyarország is próbálkozott az NPM irányzathoz tartozó reformok bevezetésével. (Meyer-Sahling 2009) Az NPM irányzat eszközrendszerének alkalmazását többek között az Európai Unió is támogatta, elsősorban pályázati források biztositásával. A reformok eredményessége általánosságban ugyan megkérdőjelezhetö, de a jelentős eltérések miatt érdemes minden egyes országot külön-külön górcső alá venni. A közép- és kelet-európai országok reformgyakorlatának mélyebb vizsgálata azonban nem célja a jelen tanulmánynak. Néhány tanulmány, amelyet a régió NPM reformjai iránt érdeklődő olvasó figyelmébe ajánlok: (Hajnal 2004), (Bouckaert et al 2009), (Nemec 2010).

9 A közösségi döntések elmélete a legfontosabb elméleti alapja az NPM-irányzatnak. Lásd erröl bővebben: (Denhardt - Denhardt 2000), (Grüning 2001).

10 Tullock, G. - Buchanan, J. M. (1999): The Calculus of Consent: Logical Foundations of Constitutional Democracy. Liberty Fund Inc, Indianapolis.

11 Downs, A. (1957): An Economic Theory of Political Action in a Democracy. Journal of Political Economy, Vol. 65, No. 2:135-150.

12 Niskanen, W. A. (2007): Bureaucracy and Representative Government. Transaction Publishers, New Jersey.
} 
közjavak, azonban a döntéshozók számára ezek magánjószágok. A problémát tovább bonyolítja, hogy mivel a közigazgatás közjószágokat hoz létre, méghozzá monopóliumként, a fogyasztók nem rendelkeznek olyan eszközrendszerrel, mint a magánjószágok estében, azaz nem képesek a keresletből és a kínálatból adódó gazdasági szankciókat alkalmazni a bürokratákkal szemben. Eszköz lehetne a kezükben a közös politikai fellépés, azonban Olson (1997) felhívja a figyelmet arra, hogy a nagyobb létszámú csoportok érdekérvényesítő képessége rosszabb, mint a kisebb létszámúaké, hiszen a szervezkedés tranzakciós költségei a csoport méretének növekedésével jelentősen megemelkedhetnek, továbbá a potyautas magatartás veszélye is számottevően megnő. Az eddigiekből következik, hogy a társadalom immunrendszere nehezen tud - akár pozitív ösztönzők, akár szankciók alkalmazásával fellépniazállamibürokratákcselekedeteiből származó, méltányosságban, eredményességben és hatékonyságban tapasztalható veszteségek ellen. E logika mentén azonban a bürokrácia korlátlanul nőhetne és használhatná ki helyzetét, mégsem ez történik. A közösségi döntések elmélete ezt azzal magyarázza, hogy a közigazgatási folyamatok összetettek, azaz sokszereplősek, és a különböző aktoroknak eltérő érdekeik vannak. A bürokraták érdeke az adott szervezet növekedése, akár a hatékonyság kárára is. Ezzel szemben a politikusokérdeke, hogy politikai hatalmukat megtarthassák, amelyhez demokratikus körülmények között az állampolgárok bizalmát kell elnyerniük - akiknek viszont az az érdekük, hogy a bürokrácia hatékonyan és eredményesen működjön. Valójában az érdekek és a hozzájuk kapcsolódó erőpozíciók bonyolult hálózata teremti meg azt az egyensúlyt, amely végül korlátozza az egyes aktorok önérdek-érvényesítő képességét. Ha képesek vagyunk megfelelő módon elosztani az egyes szereplők között az érdekérvényesítő képességet, akkor biztosíthatunk egy olyan egyensúlyt, amelyben a közjó érvényesülni képes. Az NPM irányzat által javasolt eszközök ezen egyensúlyt kívánják a különbözö szereplök - így az állampolgárok, a politikusok és a bürokraták - között megteremteni.

A közösségi elméletek logikája alapján az érintettek között hierarchikus viszony áll fenn: egy jól müködő demokráciában a bürokraták csak a politikusokon keresztül, míg a politikusok a lakosságon keresztül érhetik el céljaikat: „Demokráciában azok a hivatalnokok, akik a legfontosabb pozíciókat töltik be, nem védettek az elbocsátással szemben. A politikusokat a választók rúgják ki, míg ők nyilvánvalóan rendelkeznek bizonyos felügyelettel a közalkalmazottak felett..." (Tullock 1971:915)

\section{Az érintettek közötti hierarchia az NPM-irányzat esetében ${ }^{13}$}

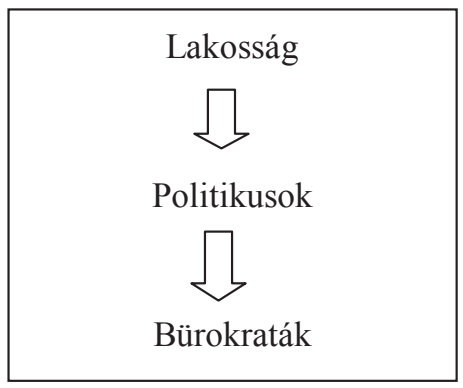

${ }^{13}$ Az ábrán erőteljes egyszerüsítéssel élek, de a föbb logikai útvonal megragadható általa. 
A közösségi döntések elemélete alapján nem csak az irányzat érintettjeit és a közöttük fennálló viszonyt tudjuk meghatározni, hanem e csoportok elsődleges céljait is.

1. táblázat

Az NPM-reformok föbb érintettjei és lehetséges céljaik ${ }^{14}$

\begin{tabular}{|l|l|}
\hline Érintettek & Elsődleges cél \\
\hline Lakosság & Jobb közszolgáltatások, kevesebb adó \\
\hline Politikusok & $\begin{array}{l}\text { Átfogó és hosszú távon stabil hatalom (újraválasztás), } \\
\text { hírnév }\end{array}$ \\
\hline Bürokraták & $\begin{array}{l}\text { Magasabb fizetés, presztízs és hatalom, jobb } \\
\text { munkakörülmények, munkahelyi biztonság }\end{array}$ \\
\hline
\end{tabular}

$\mathrm{Az}$ egyes érintettek egymásnak ellentmondó céljait az új közszolgálati menedzsment a közösségi döntések elmélete alapján hozza közös nevezőre: a politikusok számára az újraválasztás a fontos, amelyet az állampolgári igények minél szélesebb körü kielégítésével tudnak elérni, ezért az NPM irányzat a politikusok céljainak megvalósulását azállampolgárok céljainak megvalósulásához köti. A bürokraták csak a politikusok céljainak teljesülése esetén érhetik el céljaikat, azaz a bürokraták céljai ebben a rendszerben a politikusok, és így az állampolgárok céljai alá rendelődnek.

E gondolatmenet mentén összekapcsolhatjuk az NPM irányzat eszközrendszerét annak a közösségi döntések elméletéből levezetett céljaival.

\section{Az NPM célja és eszközrendszerének kapcsolata a közösségi döntések elméletéhez}

Az NPM a közszektor érintettjei közötti érdekérvényesítés kereteit úgy kívánja befolyásolni, hogy az állampolgári érdek érvényesüljön, azaz a közszektor hatékonysága javuljon. Ez azt jelenti, hogy az állampolgárok jobb minőségü közszolgáltatást kapjanak ugyanazért az árért, vagy azonos színvonalú közszolgáltatáshoz kevesebb adó és egyéb elvonások mellett jussanak. Az NPM céljait széles eszköztárral kívánja megvalósítani (Hood 1991), (Schedler - Proeller 2002:163-180), (Manning - Shepherd -Blum - Laudares 2008). Többek között a piaci koordináció erőteljesebb alkalmazásával (Dunleavy 1986), a döntések és a feladatok végrehajtásának decentralizálásával (Pollitt - Summa 1997), a lakossági igények pontos megismerésével és a lakosság erőteljesebb bevonásával, a teljesítmények mérhetőségével

${ }^{14}$ Az egyes csoportok egyéb szempontokkal és célokkal is rendelkezhetnek, így például a lakosság bizonyos része az elosztással kapcsolatos méltányossági kritériumokat is megfogalmazhat, de a legjellemzőbb célok minden bizonnyal a táblázatban felsoroltak. A fenti három csoporton kívül további lényeges érintettek például a piaci szereplök, a civil szervezetek, a tudományos közösség, a nemzetközi szervezetek. Azt is vegyük észre, hogy egyik érintett csoport sem tekinthető egységesnek. Downsra hivatkozva Eliassen és Sitter (2008:96) megállapítja: „A bürokraták típusai két véglet között helyezkednek el: az egyik véglet a törtetök (climbers) csoportja, akik a saját karrierjüket, hatalmukat és jövedelmüket helyezik a középpontba, míg a másik véglet az altruistább államférfiak (statesmen) csoportja, akik az általános jólétre törekednek, összhangban a közszolgálati ethosszal. Ezen kategóriák között helyezkednek el a fontolva haladók (conservers), akik önérdekkövetőek, céljuk, hogy stabil és elöre jelezhető módon emelkedjenek a karrierlétrán; a zelóták, akik bizonyos programok mellett elkötelezettek, és ebböl következően nyitottabbak a radikális változásra (ha ezek erösítik az általuk támogatott programokat); és végezetül a szószólók (advocates), akik a szervezetükhöz lojálisak, és akik támogatnak mindent, ami az ő saját hatáskörükbe tartozik." 
(Kuhlmann 2010), (Bouckaert - Halligan 2007) és piaci szervezetek által használt egyéb menedzsmenttechnikák alkalmazásával (Christiaens - Rommel 2008) kívánja ezen célokat elérni. Az NPM hívei - a közösségi döntések elméletének szemléletmódját követve realisták, elismerik az emberekben rejlő képességeket és felhasználják szaktudásukat, de tisztában vannak az emberek gyarlóságával is. Ezért olyan környezetet kívánnak kialakítani, ahol a közszférában dolgozók eredményesen és hatékonyan képesek saját képességeiket és készségeiket a politikusok által kijelölt célok érdekében felhasználni, azaz javítják munkafeltételeiket: nagyobb döntési szabadságot adnak abban, hogy miként kívánják a számukra kitüzött célokat elérni, és ha jól teljesítenek, akkor megjutalmazzák, azaz ösztönzik őket. Mivel az NPM hívei tisztában vannak az emberi önzésből adódó veszélyekkel, így mérhető teljesítménycélokat tüznek ki, és erőteljesebben ellenőrzik a közszektor munkavállalóit, hogy a felhasznált erőforrásokkal valóban sikerült-e a kijelölt célokat elérniük. Az NPM nem a ráfordításokra, nem a folyamatokra, hanem az eredményekre fókuszál. Az irányzat növelni kívánja a választott politikusok befolyását a célok kijelölésébe, de szakértő menedzserek kezébe kívánja adni a döntés jogát arról, hogy ezeket a célokat miként lehet a leghatékonyabban elérni. A célok kijelölése során fontosnak tartja, hogy azok számon kérhetőek legyenek, így egy-egy államigazgatási szerv számára jól megragadható, egyértelmű célokat kíván kijelölni. Ennek egyik eszköze, hogy olyan ügynökségek megalakítását támogatja, amelyek egyfókuszúak, azaz egy jól megragadható célért dolgoznak (Pollitt et al 2001); OECD 2002; Christensen - Loegreid 2005). Az NPM fontos célként jelöli meg, hogy mindenkinek, aki közpénzek felett diszponál, dönt, vagy felhasználja azt, elszámoltathatónak kell lennie (Boston 2011:20-21). Ehhez a folyamatoknak, a céloknak, az eredményeknek átláthatónak, egyértelmünek és az ezekről szóló információnak mindenki számára elérhetőnek kell lennie. Az NPM irányzat az állam működésének radikális megújítását tüzi zászlajára, ezért minden érintett tudására igényt tart. Az NPM aktív állampolgári részvételre ösztönzi a lakosságot (Callahan 2007); Häikiö 2010), hogy az egyes emberek fejében lévő egyedi ismeretek is hasznosulhassanak, illetve az állampolgári igények hatékonyan és érthetően jussanak el a politikusokhoz. Utóbbiak ezekből a közszféra munkavállalói számára egyértelmủ és mérhető célokat jelölnek ki.

\section{Az Állampolgári Érdek Mutató bevezetése a közösségi döntések elmélete alapján}

Miután bemutattuk elemzésünk elméleti keretének, azaz a közösségi döntések elméletének a jelen tanulmány szempontjából legfontosabb gondolatait, valamint összekapcsoltuk az NPM céljaival és eszközrendszerével, immár rátérhetünk annak bemutatására, miként lehetséges ezen keretrendszeren belül az NPM eredményességét számszerüsíteni. A mutatószám megalkotása elött azonban rá szeretnénk világítani a fenti gondolatmenet egyik következményére: ha elfogadjuk a tanulmányban eddig bemutatott logikai láncolatot, úgy beláthatjuk, hogy az NPM irányzat eredményességéhez elégséges kizárólag az állampolgárok érdekeinek érvényesülését mérnünk. Amennyiben tudniillik az NPM képes a közszektor három érintett csoportja közötti erőviszonyokat úgy megváltoztatni, hogy a közfolyamatok az állampolgári érdekek mentén valósuljanak meg, akkor az irányzat elérte kitűzött célját 
és eredményesnek tekinthetö. ${ }^{15}$ Ezzel azonban a problémát még nem oldottuk meg teljesen, hiszen az állampolgári érdek megragadásának módját még nem vizsgáltuk.

Ha elfogadjuk az a feltételezést, hogy az állampolgárok célja jobb minőségű közszolgáltatás fogyasztása és/vagy a kisebb adóteher, akkor láthatjuk, hogy ez a két szempont nagy valószínűséggel egymással szemben áll, s egyszerre ritkán teljesül. Egy szolgáltatás minőségének javítása legtöbbször nem a költségek csökkenésével jár együtt, hanem azok növekedésével. Ennek a problémának a vizsgálata nemcsak a mutató megalkotásánál kritikus, hanem annak végiggondolása során is, hogy milyen tényezők befolyásolják ezen indikátor értékét, azaz az NPM eredményességét. A két igény valójában ugyanannak a kívánságnak az ellentétes oldala: legyen hatékonyabb a közszektor müködése! Ebből következöen az NPM eredményességét leginkább egy hatékonyságot mérö kompozit index megalkotásával tudjuk megragadni, amelynek számlálójában a közszolgáltatások minőségét mérjük, míg nevezöjében az ezekhez kapcsolódó költségeket. Egy ilyen mutatónál minél nagyobb az index értéke, illetve egy adott időszakon belül az index pozitív változása, annál eredményesebb volt az NPM reform.

\section{Az Állampolgári Érdek Mutató felépítésének részletes ismertetése}

$\mathrm{Az}$ általunk javasolt mutató a közszolgáltatások minőségét három területen méri: az egészségügy, az oktatás és a foglalkoztatás szférájában. ${ }^{16} \mathrm{Az}$ állami szolgáltatások színvonalát minden területen egy-egy mutatóval írjuk le. Azért csak eggyel, mert sokkal több információt több mutató összegyúrásával sem tudnánk megragadni, viszont az indikátor átláthatósága sokat romlana. Egy kompozit index legfőbb előnye annak egyszerüsége és átláthatósága.

Az egészségügy színvonalát a csecsemőhalandóság (infant mortality rate) mértékével ragadjuk meg, amelyhez az adatokat az OECD Health Data adatbázisából nyerhetjük ki. Két ok miatt javasoljuk ennek a mutatónak a használatát. Egyrészről, mert a gyermek minden társadalomban érték, másrészről ez a mutató függ leginkább az egészségügy színvonalától. A csecsemőhalandóság a szakirodalomban az egyik leggyakrabban használt mutató, amellyel az egészségügy színvonalát jellemezni szokták, az OECD is elfogadja és használja (Elola - Daponte - Navarr 1995); Cantarero - Pascual 2008; OECD 2004; OECD 2010). Felhasználhatnánk még az átlagos várható élettartamot is, de ezt jóval több, az egészségügyi rendszeren kívüli tényező befolyásolja. Az egy orvosra jutó betegek számát, vagy a kórházi ágyak számát azért nem javasoljuk, mert nem rendelkezünk olyan adatbázissal, amely hosszabb idősorokat tartalmazna a fejlett nyugati országra vonatkozóan. Emellett ezek inkább mennyiségi, mint minőségi mutatók. Tisztában vagyunk azzal, hogy a csecsemőhalandóság mutatója sem tökéletes, hiszen ezt is számos szocio-ökonómiai faktor befolyásolja (Liu - Moon 1992; OECD 2004:22.

Az oktatás színvonalát a Human Development Index Oktatási Indexével (Education Index) javasoljuk mérni, amely két változót tartalmaz. Az egyik az írni és olvasni tudás mértékét méri (UNDP 2009:211), míg a másik változó az általános, a közép- és a felsőfokú oktatásba beiratkozottak arányát tartalmazza (UNDP 2009:205). Az Oktatási Index

\footnotetext{
15 Itt ismételten hangsúlyozzuk, hogy az egyes csoportok közötti kapcsolatok nem egyirányúak, a valóság jóval komplexebb, mint az általunk leírt egyirányú logika. A tanulmányunk mondanivalója szempontjából azonban a föbb összefüggés megragadása elégséges.

16 Ezek a területek a kormányzati kiadások igen jelentős részét jelentik, akár a GDP 15-30 százalékát is kiteszik (Pulpanova 2006). Részletes adatok az OECD National Accounts Statistics adatbázisból is kinyerhetők.
} 
kétharmad súllyal veszi számításba az írni és olvasni tudás jelzőszámát és egyharmad súllyal az oktatási rendszerbe beiratkozottak arányát. Ez a kompozit mutató tehát minőségi és mennyiségi szempontokat egyaránt figyelembe vesz.

Az állami szolgáltatások színvonalának harmadik mutatójául a 15 és 64 év közötti munkaképes emberek foglalkoztatottsági arányát javasoljuk. Ehhez az adatok az OECD adatbázisában találhatók (OECD 2010/a). A foglalkoztatási ráta azért került be a mutatóba, mert az Eurobarometer felmérései alapján az állampolgárok a rájuk leselkedő legnagyobb szociális veszélynek a munkahelyük elvesztését tekintik. Ezt a veszélyérzetet már az 1980-as évektől, azaz több mint harminc éve visszatükrözik az Eurobarometer felmérései. A mutató abból a szempontból semleges, hogy a kormányzat milyen lépésekkel avatkozik be, vagy nem avatkozik be a piaci folyamatokba a foglalkoztatottság növelése érdekében. Mind a be nem avatkozás, mind a beavatkozás kormányzati döntést jelent. Amennyiben egy adott időszakban bármilyen okból nő a foglalkoztatottság, azt az aktuális kormány sikerének tekinthetjük, még akkor is, ha aktívan nem avatkozott be a piaci folyamatokba, és az állami foglalkoztatottak aránya sem változott.

Tanzi és Schuknecht (1997) cikke is megerösíti, hogy a fent ismertetett három mutató alkalmas az állami érdekek mérésére. Szerintük a társadalmi jólét valamilyen módon kapcsolatban áll többek között a csecsemőhalandósággal, a középiskolai beiratkozási aránnyal és a munkanélküli aránnyal. Véleményünk szerint utóbbi a társadalmi jólét szempontjából kevésbé informatív, mint az, hogy a társadalom munkaképes korú lakosságából milyen arányban végeznek munkát. A munkanélküliek aránya az adott kormányzat által könnyebben manipulálható mutató, illetve számos esetben a társadalom bizonyos csoportjai kiesnek a látóköréből.

A közszolgáltatásokra fordított erőforrásokat, amelyek az állam méretét is meghatározzák, Hood (1995:103) alapján négy statisztikai mutató segítségével mérhetjük: a kormányzati foglalkoztatás mértéke (1); kormányzati kiadások (2); társadalombiztosítási kiadások (3); adóbevételek (4) - az elsőt a teljes foglalkoztatás százalékában, a többit pedig a GDP százalékában kifejezve.

Mivel a közkiadásokat elsősorban adókból finanszírozzák, így a GDP százalékában mért teljes állami adóbevételek nagysága fontos mutatója az állam méretének, és így költségeinek. Az állami szolgáltatások ára a lakosság számára leginkább az adókon keresztül érzékelhető. ${ }^{17}$ A mutatóhoz tartozó adatsorokat például az OECD (2009) és Lupi (2010) - Eurostat adatokat bemutató - tanulmánya alapján állapíthatjuk meg. ${ }^{18}$

Hood (1995) nem vette figyelembe azt, hogy az állam tovább nyújtózkodhat, mint a takarója ér, azaz több kiadása lehet, mint bevétele, amelyet a nemzetközi pénzpiacokról pótolhat. Ennek mérésére azt a jelzőszámot használhatjuk fel, amelyik az államháztartás eladósodottságát a GDP százalékában fejezi ki (general government gross debt in \% of GDP). Gyakran előfordul, hogy a politikai döntéshozók - akár politikai, akár egyéb okokból - nem szeretnék az állam múködésének költségeit azonnal és közvetlenül lakosságra hárítani, ehelyett állampapírokat értékesítenek a nemzetközi pénzpiacon, azaz növelik az államháztartás adósságállományát. Habár az eladósodottság azonnal és közvetlenül nem

17 A különböző adónemeket különböző mértékben érzékeli a lakosság. Ezzel kapcsolatban a Mill-hipotézist kell megemliteni, amely szerint az indirekt adók kevésbé észrevehetőek az állampolgárok számára, így alulbecsülik azokat. Erröl lásd részletesebben: Sausgruber - Tyran 2005.

${ }_{18}$ A teljes adóbevétel fogalmát a felhasznált OECD (2009:292-296)-tanulmány részletesen definiálja, így itt ettöl eltekintünk. 
érzékelhetö a lakosság számára, hosszabb távon súlyos társadalmi, gazdasági, szociális következményei lehetnek, hiszen az adósságot kamatostul kell visszafizetni a következő időszakban. ${ }^{19} \mathrm{Az}$ államháztartás adósságának GDP-arányos mértékéről az adatokat például az IMF World Economic Outlook 2010 adatbankjából nyerhetjük.

Hood (1995) alapján az állam méretének jellemzésére felhasználtuk azt az indikátort, amelyik az államháztartási szektorban foglalkoztatottak számát a teljes foglalkoztatotti állományához viszonyítja (general government sector employment / total employment). Ahogy az előző, úgy ez a mutató sem öleli fel a teljes közszektort (public sector), hanem az államháztartás (general government) keretei között marad. Sajnos a teljes közszektort leíró adatbázist egyik indikátor esetében sem találtunk. A foglalkoztatottsági számokat az OECD (2010/b) Economic Outlook adatbázisából és az Eurostattól szerezhetjük be, illetve az ILO is kiváló adatforrás.

Végezetül a mutatónk nevezőjébe beépítjük az államháztartás végső fogyasztásra fordított kiadásait a GDP százalékában mérő jelzőszámot is (general government final consumption expenditure in \% of GDP). Hood (1995), Rodric (1996) és több más szerző az állam méretét az államháztartási kiadások GDP-hez viszonyított arányával ragadja meg. Ez alkalmas ugyan az állam méretének jellemzésére, de nem vizsgálja azt a szempontot, hogy az állam mire költi el a GDP bizonyos százalékát. Az Állampolgári Érdek Mutató céljaihoz jobban illeszkedik egy olyan költségmutató, amely a közszolgáltatásokra és az állami beszerzésekre fókuszál. Az államháztartás végső fogyasztásra fordított kiadásait az Európai Unió, az ENSZ, a Világbank, az OECD és az IMF által közösen kiadott nemzeti számlák rendszerének 2008. évi leírása definiálja. (UN és további szervezetek 2009:193) E mutatót is többen használták a szakirodalomban az állami kiadások és az állam méretének jellemzésére (Yamamura 2011; (Bjørnskov - Dreher - Fischer 2007). Az államháztartás végső fogyasztásának költségeit a GDP arányában mérő mutató adatait a Világbank World Development Indicators adatbázisából nyerhetjük ki.

$\mathrm{Az}$ egyes változók bemutatása után feltehető a kérdés: akkor hogyan is áll össze ezekből az Állampolgári Érdek Mutató? Ennek kiszámításánál létrehozunk egy összevont mutatószámot, amely az állami közszolgáltatások minőségét írja le, s egy másikat, amely az állami ráfordításokat méri. Méghozzá úgy, hogy mindkét esetben egyenlő súllyal vesszük számításba a megfelelő változókat (előbbinél hármat, utóbbinál négyet). ${ }^{20}$ Ennek során az egyes elemeket standardizálnunk kell, s a fordított irányba javuló mutatókat - így például a csecsemőhalandóságot mérőt - be kell forgatnunk úgy, hogy az új indikátorban a magas

\footnotetext{
19 Buchanan és Wagner szerint a fö probléma az eladósodással pont az, hogy az adósságból finanszírozott állami szolgáltatások árát alacsonyabbnak érezzük, és többet fogyasztunk belőle, ami az állam méretét tovább növeli (James M. Buchanan And Richard E. Wagner, Democracy in Dejicit: The Political Legacy of Lord Keynes, New York, Academic Press, 1977:69, idézi: Anderson - Wallace - Warner 1986:631.

20 Az egyenlő súlyok alkalmazása ugyanolyan döntés, mintha különböző súlyokat használnánk. Lehetséges lenne az Eurobarometer alapján súlyozni a mutatókat, azaz az alapján, hogy mit tekintenek az európai országok állampolgárai fontosabb problémának. Ennek alapján az oktatás egyszeres, az egészségügy kétszeres, a foglalkoztatottság négyszeres szorzót kapna. Véleményünk szerint azonban nehéz eldönteni, melyiket tekintsük fontosabbnak, hiszen a fentin túl további módszerek alapján is súlyozhatnánk, igy például az alapján, mekkora hányadát költik a bevont országok átlagosan az oktatási, az egészségügyi és a foglalkoztatottság-politikai rendszerükre. Mivel a három közszolgáltatás aktuális fontossága élethelyzet függvénye, és élete folyamán a legtöbb ember megtapasztalja mindhárom fontosságát (gyermek és ifú korában az oktatásügy, munkaképes korban a foglalkoztatáspolitika, míg időskorban az egészségügyi szolgáltatások fontosabbak), így jogosan feltételezzük, hogy ezen közszolgáltatások egyenlő mértékben fontosak a társadalom számára.
} 
értékei jelentsék a pozitív irányt. Mindezek után átlagoljuk a három, illetve a ráfordítások esetében a négy, immár standardizált dimenziót. ${ }^{21}$

Az Állampolgári Érdek Mutatóval így már megragadhatjuk a közszektor hatékonyságát:

Állampolgári Érdek Mutató = közszolgáltatások minősége / ráfordítások nagysága

Mivel az NPM reformok sikerének megragadásához minket a változás érdekel, a mutatók meredekségével, azaz egy adott időintervallumon belüli változás nagyságával érdemes számolunk. Egy NPM irányzathoz köthető reform eredménye nem azonnal jelentkezik, így hosszabb, tíz éves időintervallumot célszerü vizsgálni. Valószínüsíthetjük, hogy azon országok, amelyek már a megfigyelt időszak elején jobb értékkel rendelkeztek, csak kisebb javulást tudnak elérni, hiszen egy magasabb szintről indulva nagyobb erőfeszítésbe kerül a hatékonyság további fokozása. Ezért érdemes kiszürnünk az Állampolgári Érdek Mutató adott időszakban mért átlagának hatását, s így statisztikailag korrigálnunk a mutatót.

Egy efféle kompozit indexnek persze nemcsak előnyei, hanem hátrányai is vannak. Nem kétséges, hogy számos olyan tényező befolyásolja az értékét, amelyeknél az NPM-reformok hatása nehezen kimutatható, vagy amely akár független attól. Emellett az állampolgárok számos egyéb érdekkel rendelkezhetnek, például bizonyos egyéneknek az egyenlőség, a szolidaritás elve fontosabb, vagy legalább olyan fontos lehet, mint az önérdek. Ne feledjük azonban, hogy a jelen mutató megalkotása során a közösségi döntések elmélete által biztosított keretek között gondolkodunk, amely önérdekkövető állampolgárokat feltételez. ${ }^{22}$

\section{Összefoglalás}

A jelen tanulmányban egy új, eddig nem alkalmazott mutatót vezettünk be, amelynek segítségével az új közszolgálati menedzsment irányzat eredményességét mérhetjük. Célunk a mutató elméleti bevezetése volt, annak empirikus tesztelésére nem vállalkoztunk. Az Állampolgári Érdek Mutatót a közösségi döntések elmélete alapján, annak keretei között dolgoztuk ki. Ez alapvetően meghatározza azon feltételeket, amelyek között eredményesen használhatjuk. Az indikátor megalkotása során elfogadtuk azt a szakirodalomban bőségesen bizonyított megállapítást (Denhardt - Denhardt 2000), hogy az NPM irányzat szorosan köthető a közösségi döntések elméletéhez, így az ezen elméletböl levezetett mutatóval képesek lehetünk az NPM által kijelölt ideális állapotot megragadni. A bevezetett mutatóval az NPM eredményességét holisztikusan, makroszinten kívántuk mérni. E magasabb absztrakciós szint előnye, hogy átfogóbban képes mérni az NPM-irányzathoz köthető reformok eredményességét, s képessé tesz bennünket különböző országok reformgyakorlatának összehasonlítására. Hátránya, hogy az indikátort több társadalmi, gazdasági és politikai folyamat egyszerre befolyásolja, s ezek hatásait nehéz szétválasztani egymástól, így az index által mutatott kép nem olyan egyértelmü, mint a mikroszintü mutatóké.

Végezetül fontosnak tartjuk kiemelni: az empirikus tesztelés hiányában nem állítjuk, hogy a most bemutatott index a legalkalmasabb eszköz az NPM-reformok eredményességének átfogó mérésére, de azt kijelenthetjük, hogy hozzájárul az erről folyó közös tudományos gondolkodáshoz. Egyetértünk Bostonnal (2000:43-44) abban, hogy „nagyobb hangsúlyt

\footnotetext{
${ }^{21}$ A statisztikai feladatok megoldásában Koltai Julia, az Eötvös Lóránd Tudományegyetem tanársegéde segített.

22 Ez a feltételezés nem tükrözi teljes mértékben a valóságot, ám a közösségi döntések elméletének kritikai elemzése nem tárgya a jelen tanulmánynak.
} 
kellene fektetni olyan közszolgálatimenedzsment-kutatások folytatására, amelyek a makroszintű vagy az egész rendszerre kiterjedő teljesítményt kutatják".

\section{Hivatkozások}

Anderson, W. - Wallace, M. S. - Warner, J. T. (1986): Government Spending and Taxation: What Causes What. Southern Economic Journal, Vol. 52, No. 3:630-639.

Barzelay, M. (2001): The New Public Management. Improving Research and Policy Dialogue. University of California Press, Berkeley

Bjørnskov, C. - Dreher, A. - Fischer, J. A. V. (2007): The bigger the better? Evidence of the effect of government size on life satisfaction around the world. Public Choice, Vol. 130, No. 3-4:267-292.

Blankart, C. B. - Koester, G. B. (2006): Political Economics versus Public Choice. Kyklos, Vol. 59, No. 2:171200.

Borins, S. (2002): New Public Management, North American style. In: McLaughlin, K. - Osborne, S. P. Ferlie, E. (eds.): New public management: current trends and future prospects. Routledge, New York:181194.

Boston, J.(2000): The challenge of evaluating systemic change: the case of public management reform. International Public Management Journal, Volume 3, Issue 1, January:23-46.

Boston, J. (2011): Basic NPM Ideas and their Development. In: Christensen, T. - Lægreid, P (eds.): The Ashgate Research Companion to New Public Management. Ashgate Publishing Limited, Farnham:17-32.

Bouckaert, G. - Nemec, J., - Nakrošis, V., - Hajnal, G., - Tõnnisson, K. (2009): Public Management Reforms in Central and Eastern Europe. NISPAcee Press, Bratislava

Bouckaert, G. - Halligan, J. (2007): Comparing Performance across Public Sectors. Working Paper, Paper for presentation to Study Group on Performance in the Public Sector. Conference of European Group of Public Administration, Madrid, 19-22 September 2007, Downloaded: http://webh01.ua.ac.be/ pubsector/madrid/papers/paper\%20Bouckaert\%20Halligan.doc, Accessed: 2011.06.20.

Buchanan, J. M. (1954): Social Choice, Democracy, and Free Markets. Journal of Political Economy, Vol. 62, No. 2:114-123.

Buchanan, J. M. (2003): Public Choice: The Origins and Development of a Research Program. http://www. pubchoicesoc.org/about_pc.php, Letöltve: 2011.08.28.

Callahan, K. (2007): Elements of Effective Governance Measurement, Accountability and Participation. Taylor \& Francis, New York.

Cantarero, D. - Pascual, M. (2008): Analysing the impact of fiscal decentralization on health outcomes: empirical evidence from Spain. Applied Economics Letters, Vol. 15, No. 2:109-111.

Christensen, T. - Lægreid, P. (2002): New Public Management: Puzzles of Democracy and the Influence of Citizens. Syposium on Accountability, Publicity \& Transparency. The Journal of Political Philosophy, Vol. 10, No. 3:267-295.

Christensen, T. - Lægreid, P. (2005): Agencification and regulatory reforms. Working Paper. Paper prepared for the SCANCOR/SOG workshop on "Automization of the state: From integrated administrative models to single purpose organizations". Standford University, 2005.04.1-2., http://soc.kuleuven.be/io/cost/ pub/paper/AgencificationRegulatioryReforms_Final21021.pdf Letöltve: 2011.06.21.

Christiaens, J. - Rommel, J. (2008): Accrual Accounting Reforms: Only for Businesslike (Parts of) Governments. Financial Accountability \& Management, Vol. 24, No. 1:59-75.

Denhardt, R. B. - Denhardt, J. V. (2000): The New Public Service: Serving Rather than Steering. Public Administration Review, Vol. 60, No. 6:549-559.

Dunleavy, P. (1986): Explaining the privatization boom: public choice versus radical approaches. Public Administration, Vol. 64, No. 1:13-34.

Dunleavy, P. et al (2005): New Public Management is dead - long live digital-era governance. Journal of Public Administration Research and Theory, Vol. 16, No. 1:467-494.

Eliassen, K. A - Sitter, N. (2008): Understanding Public Management. SAGE Publications Ltd, London.

Elola, J. - Daponte, A. - Navarr, V. (1995): Health Indicators and the Organization of Health Care Systems in Western Europe. American Journal of Public Health, Vol. 85, No. 10:1397-1401. 
Ferlie, E. - Steane, P. (2002): Changing Developments in NPM. International Journal of Public Administration, Vol. 25, No. 12:1459-1469.

Grüning, G. (2001): Origin and theoretical basis of new public management. International Public Management Journal, Vol. 4, No. 1:1-25.

Gualmini, E. (2008): Restructuring Weberian Bureaucracy: Comparing Managerial Reforms in Europe and the United States. Public Administration, Vol. 86, No. 1:75-94.

Hajnal, György (2004): Igazgatási kultúra és New Public Management reformok egy összehasonlitó esettanulmány tükrében. PhD disszertáció. Budapesti Corvinus Egyetem, Budapest. http://phd.lib.unicorvinus.hu/174/1/hajnal_gyorgy.pdf, Letöltve: 2012.03.14.

Häikiö, L. (2010): The Diversity of Citizenship and Democracy in Local Public Management Reform. Public Management Review, Vol. 12, No. 3:363-384.

Hood, C. (1991): A public management for all seasons? Public Administration, Vol. 69, No. 1:3-19.

Hood, C. (1995): The "New Public Management” in the 1980s: Variations on a theme. Accounting, Organizations and Society. Vol. 20, No. 2-3:93-109.

Hughes, O. (2008): What is, or was, New Public Management? Paper presented at the $12^{\text {th }}$ Annual Meeting of the International Research Society of Public Management, Brisbane, 27 March 2008.

Jones, L. R. - Kettl, D. F. (2003): Assessing Public Management Reform in an International Context. International Public Management Review, Vol. 4, No. 1:1-18.

Kuhlmann, S. (2010): Performance Measurement in European local governments: a comparative analysis of reform experiences in Great Britain, France, Sweden and Germany. International Review of Administrative Sciences, Vol. 76, No. 2:331-345.

Lapsley, I. (2009): New Public Management: The cruellest Invention of the Human Spirit? Abacus, Vol. 4, No. 1:1-21.

Liu, K. - Moon, M. (1992): International infant mortality rankings: A look behind the numbers. Health Care Financing Review, Vol. 13, No. 4:105-119.

Lupi, A. (2010): Tax revenue in the European Union. Eurostat Statistics in Focus. 23/2010, European Communities, Brussels. http://epp.eurostat.ec.europa.eu/cache/ITY_OFFPUB/KS-SF-10-023/EN/KSSF-10-023-EN.PDF, Letöltve: 2012.03.14.

Manning, N. - Shepherd, G. -Blum, J. - Laudares, H. (2008): Public Management Reform: should Latin America learn from the OECD? OECD:1-35, http://blog-pfm.imf.org/files/oecd-lac-publicmanagement-reforms---2008---final-1.pdf, Letöltve: 2012.03.14.

Meyer-Sahling, J-H. (2009): Sustainability of Civil Service Reforms in Central and Eastern Europe five years after EU Accession. Sigma paper No. 44, OECD \& EU. http://www.sigmaweb.org/document/32/0,3343, en_33638100_34612958_38073440_1_1_1_1,00.html, Letöltve: 2010.07.20.

Nemec, J. (2010): New Public Management and its Implementation in CEE: What Do we Know and where Do we Go? NISPAcee Journal of Public Administration and Policy, Vol. 3, No. 1:31-52.

OECD (2002): Distributed Public Governance Agencies, Authorities and other Government Bodies. OECD, Paris.

OECD (2004): Towards High-Performing Health Systems. The OECD Health Project. OEDC Publishing, Paris.

OECD (2009): Revenue Statistics 1965-2008. Special Feature: Changes to the Guidelines for Attributing Revenues to Levels of Government. OECD Publishing, Paris. http://www.oecd-ilibrary.org/taxation/ revenue-statistics-2009_rev_stats-2009-en-fr Letöltve: 2012.03.14.

OECD (2010): Better Regulation in Europe: Germany. OECD, Wien. www.sourceoecd.org/ governance/9789264085879 Letöltve: 2011.08.30.

OECD (2010/a): OECD Factbook Statistics 2010: Country Indicators. OECD Factbook Statistics (database). http://dx.doi.org/10.1787/data-00378-en Letöltve: 2011.07.27.

OECD (2010/b): OECD Economic Outlook No. 86. OECD Economic Outlook: Statistics and Projections database. http://dx.doi.org/10.1787/data-00370-en Letöltve: 2011.07.28.

Olson, M. (1997): A kollektív cselekvés logikája. Közjavak és csoportelmélet. Osiris Kiadó, Budapest.

Pollitt, C. - Bouckaert, G. (2004): Public Management Reform. A Comparative Analysis. Second Edition, Oxford University Press, Oxford.

Pollitt, C. - Summa, H. (1997): Trajectories of Reform: Public Management Change in Four Countries. Public Money \& Management, Vol. 17, No. 1:7-18.

Pollitt, C. - van Thiel, S. - Homburg, V. (eds.) (2007): New Public Management in Europe. Adaptation and Alternatives. Palgrave Macmillan Publishing, New York. 
Pollitt, C. (2002): The New Public Management in international perspective. An analysis of impacts and effects. In: McLaughlin, K. - Osborne, S. P. - Ferlie, E. (eds.): New public management: current trends and future prospects. Routledge, New York:274-292.

Pollitt, C. et al (2001): Agency Fever? Analysis of an International Policy Fashion. Journal of Comparative Policy Analysis, Vol. 3, No. 3:271-290.

Poór, József et al (2009): Similarities and Differences of Human Resource Management in Private and Public Sector Organisations in the light of New Public Management in International Comparison. Acta Oeconomica, Vol. 59, No. 2:179-206.

Pulpanova, L. (2006): Trends in government expenditure by function, 2000-2004. Eurostat Statistics in Focus. 11/2006, European Communities, Brussels. http://epp.eurostat.ec.europa.eu/cache/ITY_OFFPUB/KSNJ-06-011/EN/KS-NJ-06-011-EN.PDF Letöltve: 2011.07.27.

Rodric, D. (1996): Why do more open economies have bigger governments? Working Paper No. 5537, NBER Working Paper Series, National Bereau of Economic Research, Cambrigde. http://www.nber.org/ papers/w5537.pdf Letöltve: 2011.07.28.

Sausgruber, R. - Tyran, J-R. (2005): Testing the Mill hypothesis of fiscal illusion. Public Choice, Vol. 122, No. 1-2:39-68.

Schedler, K. - Proeller, I. (2002): The New Public Management. A perspective from mainland Europe. In: McLaughlin, K. - Osborne, S. P. - Ferlie, E. (eds.): New public management: current trends and future prospects. Routledge, New York:163-180.

Schick, A. (1998): Why Most Developing Countries Should Not Try New Zealand's Reforms. The World Bank Research Observer, Vol. 13, No. 1:123-131.

Tanzi, V. - Schuknecht, L. (1997): Reconsidering the Fiscal Role of Government: The International Perspective. The American Economic Review, Vol. 87, No. 2:164-168.

Torres, L. (2004): Trajectories in public administration reforms in European Continental countries. Australian Journal of Public Administration, Vol. 63, No. 3:99-112.

Tullock, G. (1971): Public Decisions as Public Goods. Journal of Political Economy, Vol. 79, No. 4:913-918.

UN és további szervezetek (2009): System of National Accounts 2008. UN / IMF / EU / OECD / The World Bank, New York. http://unstats.un.org/unsd/nationalaccount/docs/SNA2008.pdf, Letöltve: 2011.07.28.

UNDP (2009): Human Development Report 2009. Overcoming barriers: Human mobility and development. Palgrave Macmillan, New York. http://hdr.undp.org/en/media/HDR_2009_EN_Complete.pdf, Letöltve: 2011.07.26.

Van de Walle, S. - Hammerschmid, G. (2011): Coordinating for Cohesion in the Public Sector of the Future, Cocops Project Background Paper. Cocops Working Paper, No. 1:16.

Wollmann, H. (2003): Evaluation in public-sector reform: Towards a 'third wave' of evaluation? In: Wollmann, H. (ed.): Evaluation in Public-Sector Reform. Concepts and Practice in International Perspective. Edward Elgar Publishing Limited, Cheltenham:1-11.

Yamamura, E. (2011): Decomposition of the effect of government size on growth. Economics Letters, Vol. 112, No. 3:230-232. 